\title{
Laras dan Rumpaka dalam Garap Karawitan Jaipongan Jugala ${ }^{1}$
}

\author{
Ismet Ruchimat ${ }^{2}$, R. M. Soedarsono ${ }^{3}$, \\ Timbul Haryono ${ }^{4}$, Tati Narawati. ${ }^{5}$ \\ Universitas Gadjah Mada (UGM) Yogyakarta \\ Bulaksumur, Yogyakarta 55281
}

\begin{abstract}
This paper analyzes characteristic and musical identity of garap karawitan Jaipongan which is focused on the identity of laras and rumpaka. The identity of karawitan Jaipongan is a genre of today's Sundanese karawitan which developes without any acculturation influence. Most verbal form of rumpaka on garap karawitan Jaipongan Jugala represents a dialogue or text that requires comprehension of the content. The characteristic of laras and rumpaka which are verbal and musical in garap karawitan Jaipongan show a multidimensional artistic expression.
\end{abstract}

Keywords: characteristic, laras, rumpaka, Jaipongan, and jugala

\begin{abstract}
ABSTRAK
Tulisan ini menguraikan ciri-ciri atau identitas musikal garap karawitan Jaipongan Jugala yang dititikberatkan pada identitas laras dan rumpaka. Identitas karawitan Jaipongan merupakan suatu genre karawitan Sunda kiwari yang berkembang tanpa pengaruh besar akulturasi. Bentuk verbal rumpaka pada garap karawitan Jaipongan Jugala sebagian besar merepresentasikan suatu pembicaraan atau teks yang menuntut pemahaman isi. Karakteristik laras dan rumpaka yang bersifat verbal dan musikal dalam garap karawitan Jaipongan menunjukkan ekspresi artistik yang multidimensional.
\end{abstract}

Kata kunci: karakteristik, laras, rumpaka, Jaipongan, dan jugala

\section{PENDAHULUAN}

Sebagaimana diketahui bahwa dari sekian banyak fenomena perkembangan aktivitas musikal dalam tradisi seni pertunjukan Jawa Barat, karawitan jaipongan Jugala merupakan salah satu genre seni pertunjukan yang hingga saat ini masih memberi peran sangat besar dalam perkembangan karawitan Sunda, namun begitu kajian terhadap substansi musikal yang menunjukkan identitas serta karakteristik garap masih belum banyak dilakukan.

Dalam konvensi tradisi karawitan Sunda, biasanya para praktisi karawitan sebagian besar mengidentifikasi repertoar lagu didasarkan atas penampakan ciri-ciri musikal. Ciri-ciri tersebut dibentuk oleh konsensus pada saat terjadi interaksi auditif termasuk ciri-ciri musikal yang terdapat pada kara- 
witan Jaipongan Jugala.

Sebagai salah satu identitas karya seni yang berperan secara musikal (presentasi estetis) (R.M. Soedarsono, 2002: 123), karawitan jaipongan mampu memberi ruh dalam menghidupkan tarian. Pada masyarakat karawitan tradisi Jawa, makna tersebut dikenal dengan grupike joged (Rahayu Supanggah, 2002: 130).

Garap gending jaipongan Jugala pada awalnya mengacu pada konvensi karawitan tradisi kemudian bermetamorfosis menjadi sebuah genre karawitan baru yang dibentuk oleh baton signal (Desmon Morris, 1977: 5663, periksa pula Tati Narawati, 2003: 117). Oleh karena itu selain berperan sebagai sarana dukung dan pemberi nafas pada tari sekaligus menyertakan sifat action.

Tanpa kehadiran karawitan, tarian jaipongan sulit teridentifikasi fungsi serta peran pertunjukannya. Hal ini disebabkan bahwa ikon yang melekat pada genre pertunjukan tersebut sangat ditentukan aspek musikal karawitan yang dua di antaranya terbentuk oleh laras dan rumpaka.

\section{PEMBAHASAN}

\section{Laras dan Surupan dalam Karawitan Jaipongan}

Laras dalam karawitan Jaipongan sebagai parabot garap berperan penting dan besar andilnya dalam memberikan karakter bahkan identitas dan/atau gaya. Sebagian besar laras dan surupan yang digunakan pada $g a-$ rap gending jaipongan Jugala adalah salendro dan madenda. Kedua istilah tersebut sebagian besar diaplikasikan pada perangkat gamelan pengiring, rebab, serta vokal. Terdapat pula laras mataraman atau laras degung pada lagu Waled, Sulanjana, Polostomo naek Tokecang, namun jumlahnya sangat sedikit. ${ }^{6}$

Praktik penggunaan laras dapat ditampilkan mandiri atau merupakan gabungan sekar gending. Penggunaan laras salendro lebih banyak terdapat pada bentuk-bentuk introduksi seperti intro pada lagu Daun Pulus
Keser Bojong, Iring-iring Daun Puring, Seunggah, Bulan Sapasi.

Laras dan surupan pada karawitan jaipongan Jugala juga membingkai suasana emosional tertentu, seperti pada bait ke1 dan ke-2 dari lagu Sinden Beken terdapat ekspresi kegembiraan dan kebanggaan juru kawih yang ditampilkan dengan menggunakan laras dan surupan salendro. Kemudian laras dan surupan (modulasi) berpindah pada madenda pada saat rumpaka lagu menjelaskan sisi kekhawatiran yang disebabkan masih terdapatnya pandangan stereotip terhadap profesi juru kawih. Bait ke-3 dan ke-4 menampilkan rumpaka sebagai berikut.

\section{Ngan sok sedih aduh seueur kapeurih Lamun pareng aya anu leumpeuh yuni Mun direret sok seueur anu kapelet Sok nuturkeun mahugi teu sieun rugi Sakapeung mah sinden jadi paneumbleuhan Heunteu kaop aya anu ngadeukeutan Pajarkeun teh kade bisi bebeakan \\ Mun geus ledis osok menta pepegatan}

Contoh penggunaan laras dan surupan madenda pada bait rumpaka tersebut dapat diidentikkan dengan makna 'perlawanan' serta penegas suasana emosional (hati) juru kawih (pesinden). Dipertegas Rahayu Supanggah menambahkan bahwa laras bermakna sesuatu yang (bersifat) 'enak atau nikmat untuk dihayati', bahkan dalam lanjutan tulisannya Supanggah menjelaskan hal sebagai berikut,

Sangat besar kemungkinannya bahwa kendablegan laras dalam karawitan Jawa (pen. termasuk karawitan jaipongan) bukan semata-mata karena laras hanya memiliki peran dan makna musikal saja, lebih dari itu, laras juga merupakan sebuah produk budaya yang terbentuk melewati proses yang panjang serta dengan pertimbangan dan dilatarbelakangi oleh berbagai hal, termasuk pertimbangan maknawi, simbolis, dan filosofis dalam budaya masyarakat Jawa (2002:100)

Identitas 'laras ganda' banyak dijumpai pada lagu-lagu ciptaan Gugum Gumbira, yaitu lagu yang dinyanyikan dengan pirigan gamelan salendro dengan melodi (vokal dan 
instrumen melodis, misalnya rebab) berlaras madenda sehingga dua macam laras terdengar sekaligus. (Mariko Sasaki, 2007: 12).

Hasil analisis musikal dari contoh gending-gending jaipongan memperlihatkan bahwa 'laras ganda' dalam garap gending jaipongan Jugala merupakan sebuah pengecualian dalam arti hanya berlaku pada saat sebuah lagu dipirig gamelan salendro. Kenyataan dicermati dari fenomena penggunaan laras dan surupan madenda yang didemonstrasikan pada waditra rebab pada sesi introduksi lagu Oray Welang. Rebab ataupun vokal merupakan satu-satunya penanda laras dan surupan karena sarana pirigan lagu hanya terdiri dari tiga buah ketuk, satu buah kecrek, kempul, goong, dan kendang. Umumnya kasus-kasus seperti ini banyak digunakan pada lagu ketuk tilu, ronggeng gunung, serta topeng banjet.

Penggunaan laras dan surupan pada pirigan jaipongan meskipun sering dipertunjukkan malam hari, namun tidak pernah mengacu pada pembagian waktu sebagai tema untuk merepresentasikan tingkatan laras dan surupan.

\section{Rumpaka dalam Karawitan Jaipongan Jugala}

Rumpaka dalam karawitan jaipongan mempunyai tempat dan indentitas tersendiri saat disertakan pada model pirigan. Berdasakan latar belakang historis, kemungkinan besar jenis-jenis rumpaka pada karawitan jaipongan juga merupakan jenis-jenis rumpaka kawih igel-igelan. ${ }^{7}$ Meskipun rumpaka terkadang tidak mempunyai hubungan tema dengan pirigan gamelan.

Karakteristik rumpaka pada karawitan jaipongan lebih mencirikan sifat ekstrovert oleh karena pesan serta ungkapan dalam rumpaka mencirikan sifat keterbukaan dan cenderung tidak menampilkan kata-kata yang bersifat metafor sebagai perlambangan terhadap sesuatu yang bersifat luruh dan menunduk. Rumpaka dalam karawit- an jaipongan merupakan suatu kaidah teks yang selalu memberi ruang terbuka untuk ditafsirkan pada beragam gending.

Rumpaka lagu dalam jaipongan meskipun pada awal kemunculannya juga menampilkan beragam penafsiran khalayak tentang 'ekses seksual' yang tersimbolkan', namun sejalan dengan perkembangan musikal, tafsir 'kritis' tersebut telah berkembang dan dipahami lebih kreatif sejalan dengan perkembangan kreativitas karya Gugum Gumbira.

Andrew Weintraub menggunakan istilah 'tontonan ekses' linguistik dan visual (2012: 129), untuk memberi patokan penilaiannya terhadap dangdut. Pada batasan karawitan jaipongan, penulis berpendapat bahwa yang terjadi pada karawitan jaipongan merupakan suatu pertunjukan musikal yang menampilkan beragam aspek yang terdiri dari aspek visual (action) pada saat terjadi interaksi auditif, terutama pemain kendang saat menafsirkan garap, aspek bahasa (rumpaka) yang menampilkan keragaman stratifikasi sosial, serta aspek musikal yang secara keseluruhan memberikan ruang konsumtif pada khalayak dan para penari dalam 'menentukan' ekspresi mereka.

Di samping menggambarkan beragam makna yang merepresentasikan sebagian ungkapan perjalanan kehidupan Gugum Gumbira, makna kesedihan, makna kegembiraan, dan lain-lain, rumpaka-rumpaka lagu jaipongan sekaligus mengingatkan pada figur Undang Suwarna yang sangat produktif membantu 'pencitraan' lagu jaipongan Jugala. Begitu pula keberadaan Euis Komariah yang berperan ganda sebagai istri Gugum Gumbira yang sekaligus berprofesi sebagai penembang/juru kawih. Euis Komariah penting peranannya karena membantu 'memediasi komunikasi' antara Gugum Gumbira dengan para juru kawih pada saat proses penerapan rumpaka yang diciptakannya.

Hasil analisis rumpaka lagu-lagu jaipongan Jugala menampilkan varian rumpaka 
dengan ciri-ciri pembingkai lagu balarea (Iwan Natapraja, 2003:181), yaitu lagu-lagu umum yang bersifat kerakyatan (folk song) yang pada umumnya digunakan untuk mengiringi ketuk tilu atau kiliningan. Aspek formal lagu tradisi pada jenis ketuk tilu dan kiliningan tersebut masih banyak ditampilkan pada pirigan lagu jaipongan dengan ciriciri sifat strophik, seperti rumpaka pada jenis rarakitan, dan wawangsalan. Lagu Sulanjana yang dilantukan pesinden Idjah Khadijah merupakan salah satu dari sekian banyak lagu balarea yang menggunakan aspek formal rumpaka.

Mengacu pada aspek-aspek formal rumpaka seperti pada contoh-contoh lagu tersebut, terdapat pula beragam rumpaka yang mengacu pada tema-tema cerita yang mengungkapkan aspek kehidupan sosial, seperti percintaan dan perselingkuhan yang dikisahkan dalam jenis sekar catur antara pesinden Iyar Wiyarsih dengan Mang Samin pada rumpaka lagu Ngaruju, isu penolakan gender yang dibawakan pesinden Ijah Khadijah pada rumpaka Sinden Beken, situasi penderitaan rumah tangga yang dikisahkan dalam rumpaka lagu awet rajet dengan pesinden Umay Mutiara serta tema rumpaka tentang kesadaran hidup dibawakan Ijah Khadijah dalam lagu Kalakay Murag, bahkan terdapat rumpaka dengan napas keagamaan yang dikisahkan pada lagu Tablo naek Gendu dengan pesinden Ijah Khadijah diadaptasi dari tafsir Quran Surat (QS) Al Mu'minun ayat 12-14.

Rumpaka-rumpaka yang ditampilkan pada karawitan jaipongan Jugala tidak mengindikasikan tema-tema rumpaka yang menceritakan keindahan alam. Kata kembang (bunga) sering menghiasi beragam rumpaka lagu jaipongan namun sebagian besar mengacu pada konteks drama percintaan, seperti lagu Kembang Kasmaran.

Fakta yang berkembang dari judul serta rumpaka lagu jaipongan Jugala selain masih mengacu pada konvensi tradisi, dicirikan oleh beberapa hal seperti berikut,

- Rumpaka yang menghubungkan tema, contoh lagu Serat Salira, Waleran salira, Kopeah Buludru Hideung.

- Rumpaka yang mewakili karakteristik fisik tertentu, contoh lagu Toka-toka yang diambil dari aksesoris kostum tarian.

- Rumpaka yang yang mewakili simbol berupa uang, contoh Daun Pulus.

- Rumpaka yang mengidentifikasi struktur gending, yaitu laguning gending dan laguning sekar.

- Rumpaka yang mengidentifikasi nama koreografi. Seperti lagu senggot dengan koreografi senggot yang mengacu pada susunan komposisi sekar gendingnya.

- Rumpaka yang merefleksikan legitimasi genre jaipongan, contoh lagu Genjlong Jaipongan, Goyang Jaipong.

- Rumpaka yang merujuk pada perilaku manusia, seperti Bajidor Sohor (pesinden Titim Fatimah).

Keterikatan musikal antara rumpaka dan pirigan karawitan jaipongan sangat kuat, namun hampir dapat dipastikan bahwa rumpa$k a$ karawitan jaipongan tidak pernah tersimbolisasikan melalui gerak-gerak jaipongan, terutama karya-karya tari yang diciptakan Gugum Gumbira, seperti rumpaka lagu Serat Salira dengan koreografi Setra Sari yang tidak memperlihatkan sebuah gambaran hubungan antara gerak dan isi tema lagu. Pada gending Senggot dengan koreografi Senggot juga tidak memberikan gambaran pertautan antara Senggot sebagai lagu, Senggot sebagai judul, serta Senggot sebagai nama koreografi. Pada komposisi tari rawayan yang mengisahkan tema perjalanan dari 'tradisi ke modern', dengan laguning gending Tablo naek Gendu juga tidak dikisahkan dalam bentuk rumpa$k a$. Kesan yang ditampilkan pada kareografi rawayan ini memunculkan sebuah spekulasi bahwa rumpaka pada saat digunakan sebagai pirigan tari, beralih fungsi menjadi sarana dukung tarian, meskipun terindikasi pada contoh kasus tari rawayan ini menggunakan 
rumpaka bertema pepeling (wejangan).

Sesuai dengan perubahan waktu, perkembangan teks atau rumpaka yang pada awalnya sering menampilkan unsur-unsur lagu yang bersifat metafor serta bergaya narasi yang simbolik, terutama pada bagian syair yang dikembangkan dari unsur-unsur lagu ketuk tilu, mengalami perkembangan menjadi narasi-narasi gubahan yang bersifat verbal, seperti contoh lagu Toka-toka yang merupakan transformasi dari lagu Gaplek serta bersumber dari repertoar lagu Topeng banjet dan ketuk tilu, digubah rumpaka atau liriknya oleh Gugum Gumbira. ${ }^{9}$

\begin{abstract}
Perubahan tersebut sangat dapat dimengerti sehubungan dengan perkembangan dan pengembangan fungsi karawitan di masyarakat serta pergeseran selera masyarakat sehubungan dengan ekspose mereka terhadap dunia, termasuk seni dan budaya, serta perubahan-perubahan sosio kultural yang semakin luas, beragam, dan cepat, di samping terjadinya perubahan yang mendasar pada orientasi masyarakat terhadap kekuasaan politik dan ekonomi (Supanggah, 2002: 89).
\end{abstract}

Mengacu pada orientasi pasar (konsumerisme), rumpaka yang menampilkan tema-tema politis juga semakin tidak digunakan sebagai garapan karawitan jaipongan Jugala. Figur Mang Suwarna merupakan tokoh yang berperan penting dalam memberikan gaya serta taste lagu-lagu jaipongan. Dari perkembangan tersebut peran Mang Suwarna menjadi semakin penting dalam progresivitas karawitan jaipongan Jugala. Oleh karena itu, tidak dapat dipungkiri bahwa karya Daun Pulus Keser Bojong yang rumpakanya ditulis Gugum Gumbira, substansi lagunya, laras dan surupannya, diciptakan oleh Mang Suwarna. (Pandi Upandi, 1999: 57).

Dari hasil wawancara dengan para narasumber, sebagian besar mengindikasikan bahwa peran Mang Suwarna pada perkembangan jaipongan sangat besar. Hal ini dapat dibuktikan bahwa lagu-lagu populer jai- pongan pada karya-karya berikutnya, selain diciptakan Gugum Gumbira, tidak lepas pula dari kreativitas Mang Suwarna. Mang Suwarna tidak hanya membantu menafsirkan karakteristik lagu yang dibuat Gugum Gumbira, tetapi juga sangat produktif membuat rumpaka dan lirik lagu. Seunggah, Jamparing Langit, Iring-iring Daun Puring, Kembang Gandrung, Geter Munggaran, Mega Sutra yang diproduksi Jugala merupakan lagulagu hits jaipongan.

Tidak mengherankan apabila karakteristik lagu ciptaan Mang Suwarna kemudian turut melembagakan ciri gaya garap karawitan jaipongan Jugala, terutama ciri-ciri yang bersifat melismatis, yaitu rumpaka dengan senggol-senggol pada suku katanya terdapat beragam nada.

\section{Gaya Bahasa dan Tema Lagu}

Karakteristik gaya bahasa yang diungkapkan pada rumpaka-rumpaka lagu jaipongan cukup bervariasi, namun sebagian besar menggunakan gaya bahasa sedeng (sedang). Kecuali dwilogi lagu ciptaan Gugum Gumbira yaitu Serat Salira dan Waleran salira yang keduanya dibawakan juru kawih Ijah Khadijah dengan menggunakan rumpaka lagu dengan bahasa lemes (halus). Meskipun kedua lagu tersebut mengungkap sentimen liris, karakteristik bunyi serta irama yang digunakan pada periodik tertentu menampilkan irama ajeg atau mincid. Pada awalnya seniman-seniman seperti Iyar Wiyarsih, Idjah Khadijah ${ }^{10}$, dan bahkan Koko Koswara ${ }^{11}$ sempat mengemukakan rasa kekhawatiran terhadap karakteristik rumpaka lagu yang dibawakan dengan pola garap gending jaipongan. Seiring dengan berkembangnya perubahan waktu, aspek rasa dan selera yang dibentuk oleh budaya cukup membatasi dan menjawab persoalan terhadap situasi seperti tersebut. Andrew Weintraub menjelaskan batasan pengertian 
tentang hubungan ini dengan pernyataan sebagai berikut.

Kita seharusnya tidak mengasumsikan bahwa lirik yang mengungkap sentimen liris tertentu mesti seinduk (homolog) dengan watak bunyi musiknya, bagaimanapun sentimen-sentimen atau garapan-garapan bunyi itu didefinisikan. Misalnya, kita jangan mengasumsikan bahwa sentimen liris 'sedih' harus diiringi oleh melodi pelan yang menyayat dalam mode musikal minor. Dalam banyak jenis musik, bukan tidak lumrah sentimen melankolis dirangkai dengan tempo rancak. Anggapan bahwa lirik menuturkan cerita yang sama dengan musik menutup kemungkinan ironi, misalnya, yang bisa terjadi antara teks dan musik. Anggapan ini tidak mengizinkan kemungkinan narasi tanding (counter-narrative). (Weintraub, 2012: 157).

Pada contoh kasus lagu-lagu dangdut, fenomena serupa juga sering muncul dan membentuk ciri yang kuat dalam gaya musiknya. Andrew Weintraub menambahkan bahwa dangdut, sebagai musik komersial, sering mendahulukan pertimbangan pasar atas dasar pakem-pakem estetika formal (Weintraub, 2012: 157), begitu pula hanya pada karawitan jaipongan di mana pertimbangan pasar (profit oriented) juga merupakan salah satu orientasi. Dalam hal ini sistem konsumeris pasar turut memberikan andil dalam proses identifikasi karawitan jaipongan.

Ciri-ciri mandiri dari jenis-jenis dan gaya lagu yang diciptakan Gugum Gumbira jarang menampilkan unsur formal (formulasi/ aturan) kesastraan seperti banyak digunakan dalam konvensi rumpaka tradisi. Gugum Gumbira selalu menampilkan jenis rumpaka lagu yang mengungkapkan romantisme percintaan. Refleksi isi dari rumpaka Gugum Gumbira tidak pernah mengandung unsur sisindiran, tetapi merefleksikan suatu tema serta sedikit menyajikan pengulangan-pengulanan kalimat sejenis, sesuai dengan gending yang berjalan pada sistem kolotomik atau cyclic (Supanggah, 2002: 100).
Model pengembangan rumpaka Gugum Gumbira diadaptasi dari jenis kawih sekar catur pada lagu Teuteup Abdi menggunakan laras madenda dan salendro. Pada bait kedua dan keempat peran juru alok ngengklokan (berdialog secara verbal dengan maksud menegaskan maksud kalimat juru kawih) pada setiap akhir frase kalimat lagu.

\author{
Lagu Teuteup Abdi \\ Juru kawih (dengan penggunaan \\ laras madenda) \\ Teuteup Abdi, kang Geura tinggal abdi \\ Masing caket engkang ....ti kacaketan \\ Meungpeung urang kang ayeuna tepang \\ Sakedap deui pan urang pasti paanggang \\ $k u$ teu nyana geuningan narik simpatik... \\ (alok: atuda engkamah) \\ aduh aduh engkang abdi teu kiat ... \\ (alok: piraku) \\ ulah waka engkang abdi dikantun... \\ (alok: moal atuh) \\ ke sakedap kang sakedap deui... \\ (alok: $m h m h h)$ \\ Juru alok (dengan penggunaan \\ laras salendro) \\ aeh aeh si ayi kunaon kitu \\ asa nembean mendakan istri nu kitu \\ leumpeuh yuni sok enggal ragrag simpati \\ padahal mah pan engkang tiasa bae \\ tos kenal mah abdi teh teu panasaran... \\ (alok: ngadadak guligah) \\ bilih abdi engkang kabungbulengan ... \\ (alok: ah ulah) \\ moal isin kang mun hoyong caket \\ (alok: da maol da moal) \\ mun tos caket pan urang tiasa raket... \\ (alok: pasti atuh)
}

Gelenyu atau interlude menampilkan dialog verbal antara juru kawih dan juru alok. Kemudian juru alok berbicara verbal pada sela-sela (Gelenyu) interlude gamelan, sebelum kembali pada kalimat awal pembuka lagu dengan kalimat-kalimat sebagai berikut.

\author{
pasti atuh..pasti da bongan urang mah \\ geus deukeut \\ memang sih urang tos lawas pisan \\ urang teu tepang \\ cobi kumaha kapalay teh
}

Rumpaka kawih tidak pernah terindikasi pada jenis lagu-lagu pupuh, namun lagu- 
lagu pada jenis pupuh sering digunakan untuk kiliningan atau karawitan jaipongan, contoh sesi alok pada lagu jenis lagu lalamba yang dilantunkan juru alok kerap menggunakan pupuh dan menjadi fakta bahwa jenis pupuh digunakan pada sistem anggeran wiletan. Adapun sampel kedua lagu Tablo naek Gendu yang digunakan untuk mengiringi koreografi jaipongan rawayan, menampilkan teks atau rumpaka yang diambil dari jenis pupuh kinanti dengan menggunakan iringan embat opat wilet atau lagu yang dikategorikan pada jenis sekar tengah atau lenyepan.

Tidak terindikasi kawih pada karawitan jaipongan yang mengadopsi rumpaka topeng banjet, seperti rumpaka dan lagu Aileu. Kawih dan lagu pada jaipongan jarang sekali ditampilkan dalam bentuk rampak sekar, kecuali pada lagu Mahoni. Pada bagian refrain terdapat indikasi adanya teknik penyajian vokal yang dilakukan bersama antara juru kawih Idjah Khadijah dengan juru alok Mang Samin, namun begitu tampak secara auditif masih bersifat insidental.

\section{Dampak Lagu Jaipongan terhadap Peran Juru Kawih}

Lagu-lagu jaipongan berperan cukup penting dalam memberi karakteristik garap karawitan jaipongan, bahkan dapat dipastikan bahwa garap gending jaipongan Jugala tidak pernah luput dari menyertakan juru kawih, dan terkadang melibatkan juru alok, baik untuk keperluan garapan audio recording maupun untuk pertunjukan langsung.

Lagu, bagi seorang sinden, adalah perpaduan antara syair, melodi, embat, dan wirahma. Lagu memuat teks musikal. Ia adalah teks yang tidak hanya berupa untaian kata-kata terpilih mengikuti kaidah atau rima bahasa, akan tetapi di dalamnya sudah memuat unsur-unsur deretan komposisi nada-nada, pola struktur, tempo, dinamika, dan intensitas suara. (Endah Irawan, 2003: 103).

Karakteristik yang menonjol dari lagulagu jaipongan dapat dibedakan dari dua hal pokok sebagai berikut: pertama, lagu-lagu yang digunakan sebagai pengiring ibingan yang bersifat 'insidental'; kedua lagu-lagu yang sudah tersusun pola dan tariannya. Fleksibilitas gerak model-model kaulan (insidental dan improvisasi) berpengaruh besar pada pembentukan karakteristik lagu karena pola dan struktur lagu yang sering mengalami banyak perubahan sebagai akibat dari irama lagu mengikuti spontanitas gerak. Pada situasi seperti tersebut, juru kawih tidak hanya harus mampu mengikuti setiap perubahan irama yang harus disesuaikan dengan lagu, terkadang harus 'mengabaikan' bahkan 'membuang' kalimat lagu atau suku kata tertentu saat disajikan. Juru kawih yang berpengalaman merefleksikan lagu-lagunya dengan mengantisipasi melalui beberapa cara seperti memilih kalimat lagu tertentu agar mudah diaplikasikan, menunggu kapan saat untuk memulai dan memberikan tekanan pada akhir lagu saat ngenongkeun maupun ngagoongkeun. Contoh pada bentuk sajian ini terlihat saat juru kawih Euis Komariah membawakan kalimat nonverbal pada perubahan lagu dari gending Palimanan naek Bendrong Petit dalam komposisi tari Kawung Anten. Dengan hanya dua kata yang digunakan yaitu gandrung......dan lahhhhh, dua kata tersebut dilantunkan untuk mewaliki frase kalimat lagu (setengah wilet) menuju pada goong serta penanda perpindahan lagu.

Adapun untuk hal lain (nonseni) tidak dapat dipungkiri bahwa peran industri turut menentukan orientasi para pesinden. Tuntutan kuantitas lagu-lagu jaipongan pada volume kaset dengan durasi 6 sampai 7 menit cukup berpengaruh besar pada peran pembawaan pesinden, karena irama dapat menjadi lebih padat.

\section{PENUTUP}

Pertunjukan jaipongan muncul mewakili tradisi pertunjukan rakyat Jawa Barat dengan perwujudan gerak dan karawitan yang memikat. Sebagai bagian dari bentuk 
enchantment, garap karawitan jaipongan Jugala salah satunya ditampilkan melalui kode artistik dalam bentuk laras dan rumpaka.

Dalam mewakili citra seni pertunjukan Jawa Barat peran Gugum Gumbira sangat penting sebagai inovator Jugala. Ia meningkatan potensi artistik dan estetik laras dan rumpaka jaipongan dengan cara-cara mendiseminasikan elemen-elemen artistik dan estetik rumpaka yang pada awalnya bersifat metafor dan umumnya bersumber dari tradisi pertunjukan ketuk tilu buhun menjadi rumpaka yang bersifat lebih verbal dan musikal dengan tampilan laras yang beragam. Secara verbal rumpaka dicirikan oleh fleksibilitas struktur bahasa yang disesuaikan dengan kebutuhan ekspresi dan konteksnya dalam kehidupan sehari-hari. Hal ini memberi pengertian bahwa bentuk verbal rumpaka pada garap karawitan jaipongan Jugala sebagian besar merepresentasi suatu pembicaraan atau teks yang menuntut pemahaman isi. Dari sisi makna musikal, rumpaka dalam garap karawitan jaipongan lebih menonjolkan ekspresi kuat sebagai musikal sehingga unsur rumpaka menjadi semacam 'pengecualian' sebagai domain pertunjukan. Hal ini memberi pengertian bahwa rumpaka sebagai makna musikal mengungkapkan sesuatu yang tidak bersifat referensial.

Laras dan rumpaka yang disajikan para penggarap melalui sarana gamelan merupakan kesatuan organisasi musikal, oleh sebab itu karakteristik laras dan rumpaka yang bersifat verbal dan musikal dalam garap karawitan jaipongan tetap menunjukkan ekspresi artistik yang multidimesional.

\section{Catatan Akhir}

${ }^{1}$ Tulisan ini merupakan salah satu bagian hasil pembahasan penelitian disertasi penulis yang membahas seputar kemunculan Garap Gending Jaipongan Jugala.

${ }^{2}$ Ismet Ruchimat adalah kandidat doktor pada Program Studi Pengkajian Seni Pertunjukan dan Seni Rupa Program Pasca Sarjana Universitas Gadjah Mada.
${ }^{3}$ R.M. Soedarsono adalah Guru Besar pada Jurusan Pengkajian Seni Pertunjukan dan Seni Rupa Universitas Gadjah Mada. Saat ini R.M. Soedarsono bertindak sebagai promotor penulis dalam proses penelitian serta penyelesaian disertasi.

${ }^{4}$ Timbul Haryono adalah Guru Besar pada Fakultas Ilmu Budaya serta pengajar pada Jurusan Pengkajian Seni Pertunjukan dan Seni Rupa Universitas Gadjah Mada. Saat ini Timbul Haryono bertindak sebagai co-promotor penulis dalam proses penelitian serta penyelesaian disertasi.

${ }^{5}$ Tati Narawati adalah Guru Besar Pada Fakultas Seni Budaya, Jurusan Sendratasik Universitas Pendidikan Indonesia. Saat ini Tati Narawati bertindak sebagai co-promotor penulis dalam proses penelitian serta penyelesaian disertasi.

${ }^{6}$ Sumber kaset, Daun Pulus Keser Bojong, Iringiring Daun Puring dan Oray Welang.

${ }^{7}$ Periksa Kawih Igel-igelan dalam naskah Siksa Kandang Karesian: Naskah Sunda Kuno tahun 1518 Masehi, (terj.) Atja dan Saleh Danasasmita, (Bandung: Proyek Pengembangan Permuseuman Jawa Barat, 1981), 39-40.

${ }^{8}$ Kaset pada lagu dan album Hayang Deui (1984) dan Hayang Ayeuna (1984), dengan pesinden Umay Mutiara, produksi Jugala dengan pemain Kendang Dali Sarpingi.

${ }^{9}$ Wawancara dengan Kurnadi di Karawang, tanggal 30 Juni 2012.

${ }^{10}$ Wawancara dengan Gugum Gumbira di Bandung tanggal 6 Februari 2012.

${ }^{11}$ Wawancara dengan Atang Warsita di Bandung tanggal 21 Januari 2013.

\section{Daftar Pustaka}

Atja dan Saleh Danasasmita

1981 Siksa Kandang Karesian: Naskah Sunda Kuno tahun 1518 Masehi (terj.). Bandung: Proyek Pengembangan Permuseuman Jawa Barat.

Endah Irawan

2003 "Komparasi Senggol Sinden Populer di Jawa Barat: Hj. Idjah Hadijah, Cicih Cangkurileung, dan Cucu Setiawati". Tesis S-2 pada Program Pasca sarjana Universitas Gadjah Mada.

Iwan Natapraja

2003 Sekar Gending. Bandung: Karya Cipta Lestari. 
Morris, Desmon

1977 Man Watching: A Field Guide to Human Behavior. New York: Harry N. Abrams, Inc., Publisher.

Pandi Upandi

1999 “Dokumentasi Lagu-Lagu Ciptaan Undang Suwarna Dalam Wanda Kiliningan, Degung, Jaipongan, dan Cianjuran", Laporan Penelitian, Bandung: STSI Bandung.

Rahayu Supanggah

2002 Bothekan Karawitan. Jakarta MSPI.

2009 Bothekan Karawitan II: Garap. Surakarta: Program Pascasarjana-ISI Surakarta.

\section{R.M. Soedarsono}

2002 Seni Pertunjukan Indonesia Di Era Globalisasi. Yogyakarta: Gadjah Mada University Press.

Sasaki, Mariko

2007 Laras Pada Karawitan Sunda. Bandung: P4ST UPI.

Tati Narawati

2003 Wajah Tari Sunda Dari Masa Ke Masa. Bandung: P4ST UPI.

Weintraub, Andrew N.

2012 Dangdut: Musik, Identitas, dan Budaya Indonesia. Jakarta: Kepustakaan Populer Gramedia. 